Esta publicación cientifica en formato digital es continuidad de la revista impresa ISSN-Versión Impresa 0798-1406 / ISSN-Versión on line 2542-3185Depósito legal pp
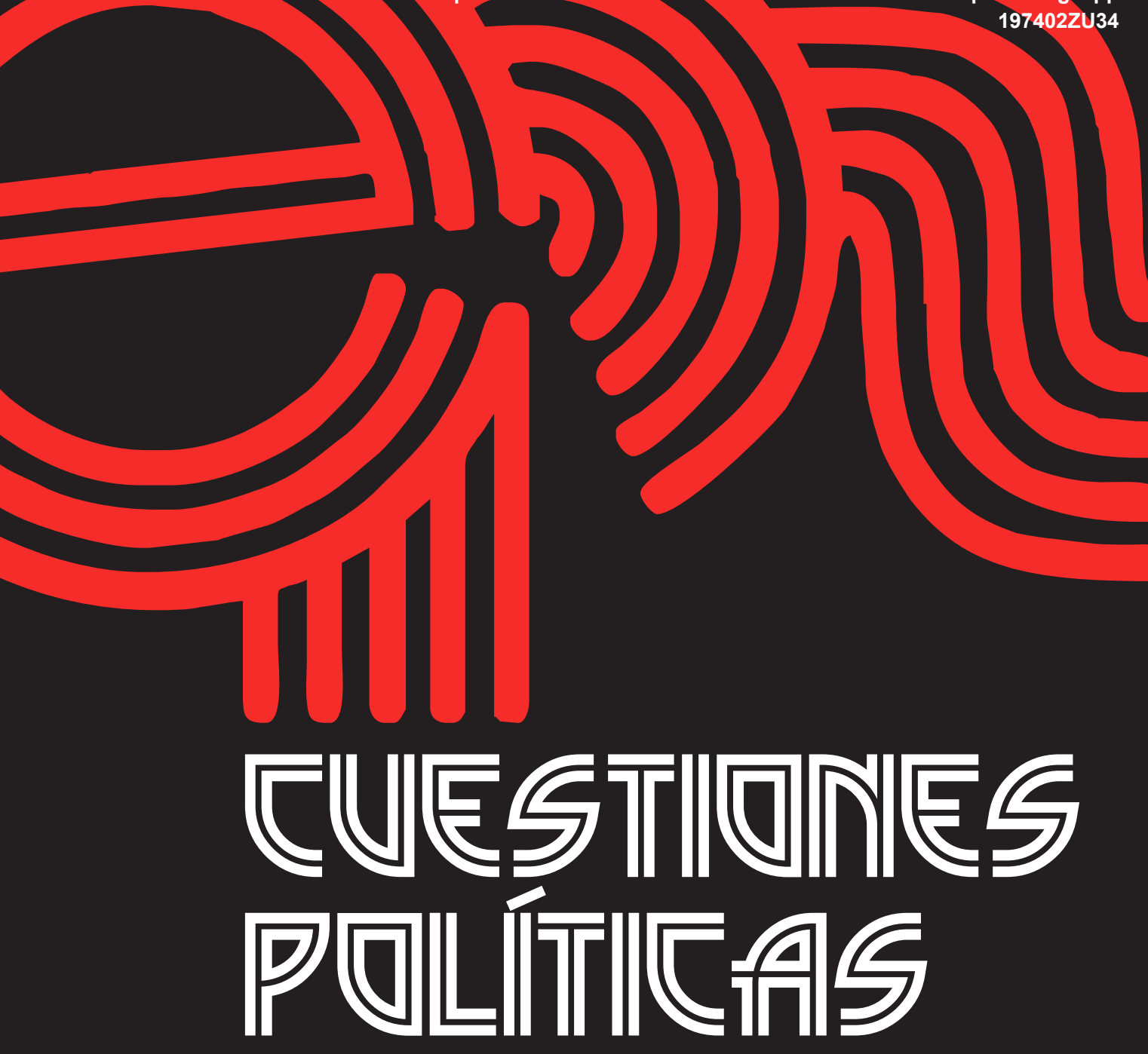

Instituto de Estudios Políticos y Derecho Público "Dr. Humberto J. La Roche" de la Facultad de Ciencias Jurídicas y Políticas de la Universidad del Zulia Maracaibo, Venezuela
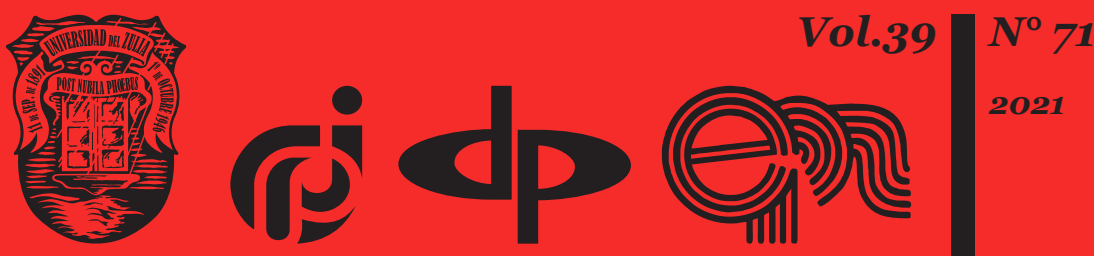


\title{
Legal and educational areas of improving civil service management systems in Ukraine and Poland
}

\author{
DOI: https://doi.org/10.46398/cuestpol.3971.19
}

\author{
Olha Bezpalova * \\ Artur Sotskyi ** \\ Andriy Shkolyk *** \\ Victor Shcherbyna **** \\ Tykhin Shevchenko *****
}

\section{Abstract}

The objective of the research was to structure conceptual approaches for the establishment, development and improvement of the formation and functioning of (civil) public management systems in Ukraine and the Republic of Poland, as well as the identification of ways and methods to improve national mechanisms for the implementation of the state personnel policy, based on the modern positive Polish experience. The positive experience of modelling an effective public (civilian) service management system in Poland that can be used in Ukraine to solve its problems has been systematized. Materials and methods were used from the analysis of documentary sources. The basis was the dialectical method of knowledge of the facts of social reality, on which formal and comparative legal approaches are largely based. Conclusions indicate that ways and directions for further reform of the management system in the field of public service in Ukraine, include the further integration of the national public service model, and management mechanisms in this area to the standards of the single administrative area within the framework of the Association Agreement between Ukraine and the European Union.

* Doctor of Jurisprudence, Professor, Honored Science and Technology Figure of Ukraine, head of the department of Police Activity and Public Administration of the Faculty No. 3 of Kharkiv National University of Internal Affairs. ORCID ID: http://orcid.org/oooo-0003-2886-695X

** Candidate of Law, Associate Professor, Chernivtsi Institute of the International Humanities University, Head of the Department of Jurisprudence. Ukraine. ORCID ID: https://orcid.org/oooo-0001-68367480

*** Doctor in Law, Professor, Administrative and Financial Law Department, Ivan Franko National University of Lviv. Ukraine. ORCID ID: https://orcid.org/oooo-0o02-8215-2715

**** Doctor of Juridical Sciences, Professor at the Department of Labor and Social Maintenance Law Taras Shevchenko National University of Kyiv. Ukraine. ORCID ID: https://orcid.org/oooo-0002-56945121

***** Candidate of Law, Senior Lecturer of the department tactical and special physical training of the faculty № 3 of Kharkiv National University of Internal Affairs. ORCID ID: https://orcid.org/oooo0003-0366-7217 
Keywords: public service; civil service; public service management system; reform of the public service; comparative law.

\section{Áreas legales y educativas para mejorar los sistemas de gestión de la función pública en Ucrania y Polonia}

\section{Resumen}

El objetivo de la investigación fue estructurar enfoques conceptuales para el establecimiento, desarrollo y mejora de la formación y funcionamiento de sistemas de gestión pública (civil) en Ucrania y la República de Polonia, así como la identificación de formas y métodos para mejorar los mecanismos nacionales para la implementación de la política de personal estatal basada en la experiencia polaca positiva moderna. Se ha sistematizado la experiencia positiva de modelar un sistema eficaz de gestión del servicio público (civil) en Polonia que se puede utilizar en Ucrania para resolver sus problemas. Se emplearon materiales y métodos a partir del análisis de fuentes documentales. La base fue el método dialéctico de conocimiento de los hechos de la realidad social, en el que se sustentan en gran medida los enfoques jurídicos formales y jurídicos comparados. Conclusiones indican que las vías y direcciones para seguir reformando el sistema de gestión en la esfera del servicio público en Ucrania incluyen el fortalecimiento de la integración del modelo de servicio público nacional y los mecanismos de gestión en esta esfera hasta los estándares del espacio administrativo único dentro del marco del Acuerdo de Asociación entre Ucrania y la Unión Europea.

Palabras clave: servicio público; servicio civil; sistema de gestión del servicio público; reforma del servicio público; derecho comparado.

\section{Introduction}

Development of Ukraine as a successful European state depends first and foremost on the success of public administration and public service reform during the transformation period. It is the professional and virtuous body of civil servants that is called to become the leader of progressive changes in society and the state. And in general the positive reform of the public service (separation of political and administrative positions; introduction of competitions for all vacant public service positions, approval of the institution of state secretaries, etc.) carried out in Ukraine in 2015-2019, 
today, in 2020, requires reinterpretation of its results and achievements, as well as determination of new goals and priorities for their further development. In particular, this should be done in terms of improving the mechanisms of organization and operation of the public service management system in Ukraine, taking into account the best practices of the member states of the European Union. The experience of civil service creation in the Republic of Poland is the closest and most comprehensible for Ukraine.

\section{Literature review}

An equally important point for the theory and practice of public service in Ukraine today consists in a constructive response to the global challenge to ensure effective control in the sphere of formation and provision an effective public service management in conditions of overcoming the coronavirus pandemic (COVID - 2019). It is obvious that the procedures for temporary selection for the public service for the period of quarantine (Demmke, 2003) only partially solve this problem and are currently subject to sharp criticism by the EU. These and other issues of organization and functioning of the public service management system in Ukraine need to be urgently solved on the basis of relevant scientific developments and taking into account positive foreign experience. Since during the last five years reforming of the public service in Ukraine has been based on the phenomenology experience "civil service creation" in the Republic of Poland it will be appropriate to analyze and compare the public service management systems in Ukraine and the Republic of Poland.

\section{Material and methods}

A set of general scientific and special research methods was used in the work which gave an opportunity to ensure comprehensiveness of studying the problem as well as reliability of the research conclusions. The main research methods are the systematic method, which contributed to disclosure of the basic public service elements and principles; method of historical analysis which appeared to be the basis for describing the current state and development of the public service; structural and functional method which made it possible to take into account most of the features of service and focus on the problems and prospects of civil service in administrative reform conditions, as well as methods of analysis and synthesis used at all stages of writing this work. Combination of these and other methods and techniques has made it possible to ensure comprehensiveness of studying the problem as well as reliability of the research conclusions. 


\section{Results and discussion}

Established in the 21st century views on the public service as a special regime for citizens endowed with appropriate competence to exercise functions of the state, or as a body of civil servants ensuring the legal personality of the state, implementation of its internal and external functions give the most general idea of this important institution for the society and the state. At the same time, the civil service, like any resourceintensive institution of public administration, requires its rational and effective use in the interests of the people and the state.

In our opinion, the public service management is a determined by the Constitution and laws of Ukraine, purposeful, administrative, organizational and governmental activity of the state authorities, aimed at: 1) Identification, harmonization and implementation of a common public personnel policy in the sphere of the public service with broad attraction of the community; 2) implementation of international standards in the sphere of public service; 3) approval of a comprehensive and balanced system of civil service management, represented by entities that: a) form public policy in the sphere of public service, taking into account international standards; b) implement the public personnel policy and provisions of the current legislation, strategies and programs on public service issues; c) provide training, retraining and advanced training of the public service body; 4) formation and permanent renewal of educated, highly professional, patriotic and virtuous body of the public service, which should be carried out transparently on a competitive basis; 5) prevention of conflict of interest, nepotism and any manifestations of corruption during the entry into the public service and throughout its duration; 6) organization of continuous professional training, retraining, specialization and advanced training throughout the public servant's career; 7) ensuring social and legal protection of public servants, increasing the public service prestige in the society and the state.

In its turn, the public service management system is an established by the current legislation hierarchy of subordinate and coordinated functioning of public administration subjects, as well as a system of tasks, functions and powers, methods, forms and mechanisms for formation and realization of personnel policy in the sphere of public service. Its key features are: a) legality and legitimacy; b) taking into account national traditions and international standards of public service management; c) hierarchy (the so called "personnel vertical") in combination with democratic nature; d) unity combined with collegiality; g) integrity and prevalence of activity throughout the territory of state; integration into the national system of state executive authorities with the involvement of the public service in the parliament, office of the head of the state and judicial power administration etc. 
Olha Bezpalova, Artur Sotskyi, Andriy Shkolyk, Victor Shcherbyna y Tykhin Shevchenko Legal and educational areas of improving civil service management systems in Ukraine and Poland

The public service management systems in Ukraine and Poland have undergone a long and largely similar genesis and evolution since the 9th century. At his time in the middle of the 19th century the German scientist G. Ahrens wrote:

\begin{abstract}
Slavs appear divided into two great tribes. Now based on their place of residence and peoples that make them these tribes form two branches: BohemianPolish, or North-Western branch including Moravians, Czechs, Poles and Wends in close relations, and Russo-Serbian, also called Russo-Illyrian, or South-Eastern branch composed of the Russians belong, that is, the Great Russians, the Little Russians, the Russinians (Rusyns or Ruthenians), the Bulgarians, and various tribes of the Illyrian Slavs. There is more similarity between the Germanes and the Slavs in language and character than between the Germanes and the Celts; but the Slavic character differs from the Germanic in the dominance of feelings and ideas, often with a greater desire for the public..." (Ahrens, 1862: 524).
\end{abstract}

In our opinion, the above expansive quotation testifies not only to the difference in views of Slavic and German scholars on the origin of the Slavic peoples, but also to the fact that Poles and Russians have long been independent. However, the assertion of their statehood, as well as the beginning of the public service, falls at the 9th century At that time, the public service in the Kyiv principality was organized by legendary princes Yaroslav, Volodymyr and others, and the Polish Principality was ruled by Prince Mieszko, Bolesław I the Brave, Mieszko II, Casimir, etc. (Goldryng, 1928), and to the modern systems of the public service management in Ukraine and Poland in the 21st century.

The Prince could solve all issues of state life, including appointment of administration foreman, centurion and thousanders). The prince's court (as a power institution) managed economic, cultural, religious processes, and in order to perform these functions numbered about a hundred of persons. It should be noted that the state apparatus of the Grand Duchy of Lithuania owing a part of Ukrainian lands was quite specific. As in the Kyivan Rus, the duke ruled the state affairs through his squad, which included land aristocracy. However, expansion of the borders of the Dutchy and entry of a number of new lands led to the need to modernize and complicate the state apparatus.

The wife was transformed into a Duke's Court which was the only institution of the state apparatus during the 4th century. The first officials who appeared in the structure of the court were voyevodes (military leaders) and tivunkis (volost leaders), as well as clerks (scribes and treasurers). With the abolition of appanage principalities and the formation of regions and voivodships, they were replaced by the positions of elders and voivodes, who performed not only military functions; and later positions of courtiers, marshals, cellarers, cornets etc. The highest military authority (after the 
duke) was given to o the hetman who was entrusted with the leadership of the army during campaigns. The mentioned posts were multifunctional, i.e. one person could hold several positions simultaneously. Positions of deputies, city governors, chastelains etc. were introduced within the regions in order to control collection of taxes and the organization of construction and maintenance of roads and fortifications in proper condition.

Avoiding disclosure of the genesis and evolution of the public service in Ukraine and Poland, which deserves its own study, we note that the establishment of national public service systems, in their modern sense both in Ukraine and Poland took place at the beginning of the 2oth century, after the revival of our statehood. Up to date reforms of public Poland, which is a member of the EU, are a good example for Ukraine in its integration processes.

Thus, the main periods of formation and development of public service management systems in Ukraine and Poland are:

- The first period (the 9th century. - the 13 th century) - establishment of the public service management system in the Kyivan and Polish principalities;

- The second period (the 13th century. - the 14th century) - the decline state institutions in the Kyivan principality during the Orda times, development of Halych and Volyn' Principality: and formation of the Grand Duchy of Lithuania, where the feudal-valesal model of public service management was launched;

- The third period (the 14th century. - the 18th century - establishment and development of the public service management at the time of the formation of the Lithuanian-Polish Union, and since 1569, after theUnion of Lublin - the Polish-Lithuanian Commonwealth (Rzeczpospolita) as well as establishment of the Cossack state phenomenon and the strengthening of the public service basis;

- The fourth period (the 18th century the 2oth century). - Ukrainian and Polish lands in the Russian and Austria-Hungary Empire and the attachment of aristocratic and discriminatory public service management systems based on the legislation of the respective metropolitan areas;

- The fifth period (beginning of the 2oth century - middle the 2oth century). - birth of the national systems of state service management for the days of national-liberation competitions of the UPR- WUPR 1917-1922 and during the period of revival of the Second Rzeczpospolita in Poland (1918-1939);

- The sixth period (the first part of the 2oth century - end of the 2oth century). Introduction of the Soviet state-party system of public 
Olha Bezpalova, Artur Sotskyi, Andriy Shkolyk, Victor Shcherbyna y Tykhin Shevchenko
372 Legal and educational areas of improving civil service management systems in Ukraine and Poland

service management in Ukraine (1922) And introduction of the communist model of public service in the Polish People's Republic after the Second World War;

- $\quad$ The seventh period (end of the 2oth century - beginning of the 21st century). - revival of national public service management systems after the "Velvet Revolution" in Poland and during the Third Rzeczpospolita and after the proclamation of Ukraine's independence in 1991; adoption of the first laws on public (civil) service in Ukraine (1993) and Poland (1998);

- $\quad$ The eighth period (from the beginning. Of the 21st century - till now) - reforming the public (civil) service management system based on the values of the United Europe and adoption of new laws on the public (civil) service in Poland (2008).

It should be noted that each country in the world has its own model of public service, as well as its own system of public service management, in particular the civil service management. At the same time, states that have related legal and administrative systems, common aspects of genesis and evolution of their state-building and law-making, public administration and public service, as well as similar problems in the sphere of public service and approximate ways of solving these problems have also public service management systems of similar nature. The public service management system in Ukraine and the civil service management system in the Republic of Poland are a clear example of this.

Taking into account the normative content of Article 12 of the current Law of Ukraine "On Public Service" (Law of Ukraine, 2013), the system of public service management bodies in Ukraine should be understood as a system of legally defined and hierarchically organized subjects of public administration with general Cabinet of Ministers of Ukraine and special (central executive power body) Committee on Senior Public Service body and relevant tender commissions; heads of the public service; personnel management services), competence as well as specialized educational institutions (the National Academy for Public Administration under the President of Ukraine, etc.) and research(scientific) institutions, and a system of their standardized and interdependent functions and powers that ensure the formation, renewal and functioning of civil servants in Ukraine (Leheza et al., 2021).

Instead, in the Republic of Poland, the system of public (civil) service management is similar to the Ukrainian one and is represented by the following subjects described in our previous publications (Fedorenko, 2020):

- Head of the Civil Service subordinated directly to the Head of the Council of Ministers of Poland p. 7 Art. 148 of the Constitution of 
Poland (Law of Poland, 1997) and appointed / dismissed by the government, formulates and implements the state personnel policy and manages the civil service in Poland;

- The Civil Service Council consisting of 15 members, as an advisory body on matters related to the preparation of human resources management strategy in the civil service, preparation of bills and drafts of other regulations and programs in the sphere of civil service, budget requests for funding of the civil service, qualification requirements for candidates for civil service positions, as well as issues of ethical and disciplinary liability of civil servants, etc. Activities of this Council are provided by the Office under the President of the Council of Ministers of Poland;

- Director General of the Government, whose position is formed at the Chancellery of the Council of Ministers, ministries and government committees, central executive bodies and voivodship (province) governments, as well as at the Office for Registration of Medicinal Products, Medical Devices and Biological Products and the Forest Seed Bureau. The Director General is subordinated to the head of the relevant executive body. The posts of the Director General are not created t the General Command of the Police, the General Command of the State Fire Service and the Command of the Border Guard;

- Head of the department at the Office of the Council of Ministers, ministries and governmental committees, central executive bodies and at the governments of the voivodships;

- Lech Kaczyński National School of. Public Administration (Krajowej Szkoły Administracji Publicznej im. Prezydenta Rzeczypospolitej Polskiej Lecha Kaczyńskiego, KSAP) (named after the president of the Republic of Poland) which carries out professional training, retraining and advanced training of civil (public) servants in Poland.

This system became an instrument and the result of the complex process of civil service creation in the Third Polish Republic (III Rzeczpospolita). The phenomenon of "civil service creation" in the Republic of Poland consists in the fact that since 1998 a new "civil service" has been created (and alongside with it two more components of public service (service tlocal government bodies ("stużba samorządowa") and military and paramilitary service ("stużba mundurowa") are presented, and a balanced system of state personnel policy and civil service management has been formed. This generally contributed to integration of Poland into the single European administrative space and, finally, in 2008, it became an EU member state (Leheza et al., 2021). 
The successes of reforming the public service management system in Ukraine, taking into account the Polish experience, in 2014-2019 opened similar prospects for European integration of Ukraine, but today the public service reform needs to be completed, without compromises in terms of "quarantine procedures". Moreover, given the spread of the practice of passing state examinations and defending dissertations in Ukraine through Zoom software applications and other applications used on the global Internet.

In addition to that development of the public service management system in Ukraine in 2019-2020 demonstrates ambiguous trends that distance the public service model in Ukraine not only from Poland, but also from the EU as a whole. These "reverse transformations" include the following: unreasonable delay of the Parliament with adoption of the new Law of Ukraine "On Service in Local Self-Government Bodies" (Law Of Ukraine, 2001) which was to be adopted simultaneously with the Law of Ukraine "On Public Service" in 2013 (Law of Ukraine, 2013); lack of global international donor projects on reforming the public service in Ukraine; weakening the position of the Senior Public Service Commission and its "forced unemployment" during the COVID-19 pandemic in 2020; outflow of representatives of civil society institutions from personnel commissions; introduction of a novelty into the legislation when competitive selection takes place according to part 1 of Article 28 of the Law of Ukraine "On Public Service" (Law of Ukraine, 2013) ubiquity of appointments to positions of category " $A$ " and " $\mathrm{B}$ " in the "coronavirus" mode, without competitions; transfer of the National Academy for Public Administration under the President of Ukraine to the Ministry of Education and Science of Ukraine, etc. However, these "reverse transformations" are not fatal and, in our opinion they are subject to constructive solution. This can be done taking into account the positive experience of civil service creation in Poland (Leheza et al., 2021).

And what are the similarities and differences of the researched public service management systems? Public (civil) service management systems in Ukraine and Poland are similar, but not identical. They have hierarchical structure and, in fact, they form the managerial vertical of "personnel authority". These systems, in their broad sense, are represented by: a) parliaments that regulate the public service institution at the legislative level; b) general executive bodies (the government, head of the government) and special competence (commissions on public service, specially authorized bodies or officials on public service regulation; heads of the public service (state secretaries, directors general, personnel services (departments) and divisions). At the same time, unlike Ukraine, the public (civil) service management system in Poland is concentrated primarily under the Head of the Council of Ministers of the Republic of Poland responsible for formation and operation of the Civil Service Council, as well as under the Head of the 
Civil Service who is subordinated directly to the Prime Minister. Instead, in Ukraine, the central entity of the Public Service management is presented by the National Agency for Public Service of Ukraine which is subordinated directly to the Cabinet of Ministers of Ukraine and ensures activities of the Senior Public Service Commission. In our opinion, the Polish model (with the head of the Civil Service being the central subject of the Civil Service) may be promising for Ukraine as well, given the established legal management status of the sole head of the public service who is appointed and dismissed by the government (Liutikov et al., 2021).

Poland also has a unified vertical of "personnel authority" when directors general of the government are heads of the civil service in the entire system of executive power bodies - from the Office of the Council of Ministers of the Republic of Poland to central executive bodies and military administrations (voivodships). Instead in Ukraine state secretaries operate at the Secretariat of the Cabinet of Ministers of Ukraine as well as at ministries while heads of the state service at other central executive bodies (state services, state inspections, state agencies and central executive authorities with a special status) are heads of these central executive authorities. Thus, change of the head of a central executive authority generally brings about radical changes in the personnel policy and public service management at the departments.

It should also be noted that an important component of the system for implementation and formation of state personnel policy and the civil service management in Poland is presented as State School of Public Administration (KSAP). Thanks to the special professional training graduates of this school have preferences regarding holding vacant civil service posts. Instead, in Ukraine, after transferring the National Academy for Public Administration under the President of Ukraine (NAPA) to the Ministry of Education and Science of Ukraine in November 2020, the issue concerning the entity (entities) for provision of training, retraining, specialization and advanced training of civil servants requires its constructive solution (Pryimachenko et al., 2021).

\section{Conclusion}

So, the main ways and directions for further reforming the system of management in the sphere of public servicein Ukraineinclude: Strengthening of the integration of the national public service model and management mechanisms in this sphere up to the standards of a single administrative space within the framework of the Association Agreement between Ukraine with the European Union; b) conducting a system audit, involving SIGMA international assessment tools (Support for Improvement in Governance and Management), etc., main achievements and miscounts of the public 


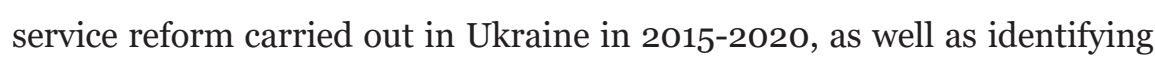
prospects for modernization of the civil service management system in Ukraine for the next three years; c) performing functional examination of the main components of the state service management system in Ukraine and ensuring the discussion of its results with the public (community), as well as returning the community to competitive commissions, which determine the winners for holding vacant posts of the public service; d) strengthening of the state-management status and independence guarantees of the Senior Public Service Commission providing change of its name as the Senior Public Service Commission under the Prime Minister of Ukraine; g) abolition of dubious innovations on determining the winners "not more than five people per position" (Part 1 Art. of Article 28 of the Law of Ukraine "On Public Service") and suspension of the provisions of the same Law during quarantine caused by the COVID-19 pandemic as those which, in fact have reduced the transparent nature of the public service reform and significantly weakened the public service management system in Ukraine, etc.

\section{Bibliographic References}

AHRENS, Heinrich. 1862. Encyclopedia of Law. L. Philosophy of law, philosophical review of the history of law and the history of positive law among the peoples of the East, Greeks, Romans, Germans and other European peoples / per. with him. In the printing house of A. Semyon, IV p. 524. Moscow, Russia.

DEMMKE, Christoph. 2003. Civil service in the accession countries. Trends and influence of integration processes. European Institute, 317. Łódź, Poland.

FEDORENKO, Vladislav. 2020. "Civil service management systems in Ukraine and Poland: comparative legal aspect" In: Bicunk of Luhansk State University of Internal Affairs named after E. A. Didopenka. Vol. 91, No. 3, 91, pp. 205-217.

GOLDRYNG, Heinrich. 1928. An abbreviated textbook of Polish history. Prof. Dr. Anatol Lewicki. Issue III. Published by A.F. Mitytler. $96^{\text {th }}$. Lodź, Poland.

LAW OF POLAND. 1997. The Constitution OfThe Republic Of Poland. Available online. In: https https://www.sejm.gov.pl/prawo/konst/angielski/kon1. htm. Consultation date: 14/03/2021. 
LAW OF UKRAINE. 2001. About service in local governments. Available online. In: https://zakon.rada.gov.ua/laws/show/2493-14\#Text. Consultation date: 19/03/2021.

LAW OF UKRAINE. 2013. About administrative services. Available online. In: https://zakon.rada.gov.ua/laws/show/5203-17\#Text. Consultation date: 19/03/2021.

LEHEZA, Yevhen; DOROKHINA, Yuliia; SHAMARA, Oleksandr; MIROSHNYCHENKO, Serhii; MOROZ, Vita. 2021. "Citizens 'participation in the fight against criminal offences: political and legal aspects" In: Cuestiones Políticas. Vol. 39, No. 69, pp. 212-224.

LEHEZA, Yevhen; ODYNTSOVA, Iryna; DMYTRENKO, Natalia. 2021. "Teoría y regulación legal del apoyo informativo de los procedimientos administrativos en Ucrania” In: Ratio Juris UNAULA. Vol. 16, No. 32, pp. 291-306.

LEHEZA, Yevhen; TIUTCHENKO, Svitlana; STANINA, Olha; SHATRAVA, Serhii; REZANOV, Serhii. 2021. "Uso y protección del suelo: regulación legal y experiencia extranjera” In: Revista De La Universidad Del Zulia. Vol. 12, No. 33, pp. 70-81.

LIUTIKOV, Pavlo; SHEVCHENKO, Mykhailo; PRYIMACHENKO, Dmytro. 2021. "Judicial review of the exercise of discretionary powers: case-law of European court of human rights and experience from Ukraine" In: Journal of law and political sciences. Vol. 26, No. 1, pp. 400-425.

PRYIMACHENKO, Dmytro; IVANSKYY, Andriy; LIPYNSKYI, Matvieiev Vladyslav; POVOROZNIK, Artem. 2021. "Counteracting illegal border crossing and human trafficking: comparative analysis” In: Amazonia Investiga. Vol. 10, No. 42, pp. 196-205. 

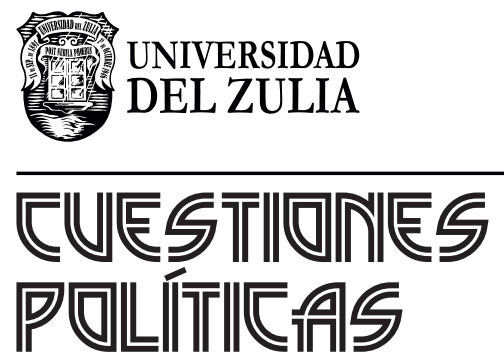

Vol. 39 N $^{\circ} 71$

Esta revista fue editada en formato digital y publicada en diciembre de 2021, por el Fondo Editorial Serbiluz, Universidad del Zulia. Maracaibo-Venezuela 